\title{
Die boodskap van Romeine
}

\section{(Ter herinnering aan my leerling, vriend en kollega, wyle prof JI de Wet)}

\section{BJ ENGELBRECHT}

1. Die man wie se persoon en werk ons in hierdie uitgawe van die HTS herdenk, se teologiese uitgangspunt in sy BD-lesings, DD-privatissima en publikasies was die formele beginsel van die Protestantisme, naamlik: sola et tota Scriptura. Hy was daarvan oortuig dat die Heilige Skrif nie net die bron en norm van die gelowige se geloof en lewe is nie, maar óók van alle kerklike lewensverrigtinge èn van die wetenskaplike besinning daaroor in die homilitiek, liturgiek, kategetiek en poimeniek. Hy het met nougesette ywer na die riglyne vir die lewenspraktyk van die kerk en vir die Praktiese Teologie gesoek en dit geformuleer. Hy was nie totaal afwysend teenoor die sg. "Hulpwetenskappe" van die Praktiese Teologie nie, maar hy het hulle baie krities beskou en hanteer. Die Praktiese Teologie moes sy selfstandigheid as teologiese vak nooit prysgee nie; dit was sy eerste eis en die tweede was: Wanneer die Hulpwetenskappe wel gebruik word, mag hulle nooit die Bybelse riglyne in gedrang bring nie.

2. Wat ons in hierdie artikel beoog, is om die groot riglyne van "Die brief van die apostel Paulus aan die Romeine" en hulle onderlinge samehang aan te toon. Dat hierdie riglyne uit hierdie beroemde brief in beide die teologiegeskiedenis èn kerkgeskiedenis wel betekenis vir die leer en lewe van die gelowige het, ly geen twyfel nie. In hoeverre dit betekenis vir die grondslae, metode en inhoud van die Praktiese Teologie het, sal deskundiges op dié gebied moet sê. In elk geval: Ons hoop om 'n klein bydrae te lewer om die Skrif te laat spreek en sekere riglyne te trek - 'n lewensideaal van wyle professor De Wet.

3. Hier volg nou die kort uiteensetting:

\section{'N KLEIN STUKKIE HISTORIESE AGTERGROND}

So ongeveer in die jaar $57 \mathrm{nC}$ het Paulus sy derde sendingreis voltooi en was hy, volgens Rom 15 vers 25 en 26, op pad na Jerusalem om die 
bydraes van die gemeentes van Macedonië en Achaje vir die arm Christene in Jerusalem oor te bring. Sy taak in die Ooste was afgehandel. In Rom 15 vers 23 sê hy: "Maar nou dat ek geen plek meer in hierdie streke oor het nie ... sal ek na julle kom wanneer ek na Spanje reis." Paulus is dus van plan om nou in die Weste te gaan werk.

In die eerste plek het hy Rome in gedagte gehad. Hy was ongetwyfeld bewus van watter groot betekenis die vestiging van die Christendom in hierdie invloedryke hoofstad van die destydse beskaafde wêreld sou hê. Daar was alreeds 'n Christelike gemeente in Rome wat nie deur Paulus se toedoen nie, maar deur die arbeid van evangeliedienaars wat vir ons onbekend is, tot stand gekom het. Nou skryf Paulus aan die Christene in Rome met die volgende in gedagte: Eerstens om aan hulle die evangelie te verkondig (Rom 1 vers 15); tweedens om aan hulle die een of ander genadegawe mee te deel sodat beide hulle èn Paulus onderling in die geloof bemoedig kan word (Rom 1 vers 11 en 12); derdens om deur die gelowiges in Rome "na Spanje voortgehelp te word, as ek eers 'n tyd lank van julle geniet het" (Rom 15 vers 23).

Paulus skryf hierdie brief heel waarskynlik vanuit die stad Korinthe. Van die baie gegewens wat uit Hand 20 en uit Paulus se groetelys in Rom 16 in hierdie rigting wys, noem ons slegs die één saak: In Rom 16 vers 1 beveel Paulus die diakones, Fébé, by die gelowiges in Rome aan en daar sê hy dat sy van Kenchrèë af kom, dit wil sê van één van die twee hawens van die stad Korinthe. Hy stuur heel waarskynlik hierdie brief (wat deur Tértius as sekretaris opgeteken is - Rom 16 vers 22 ) saam met Fébé na Rome toe.

In die brief aan die Romeine vind ons 'n vollediger uiteensetting van Paulus se leer en prediking as in enige ander brief. Dit is ' $n$ vraag waarom Paulus juis in hierdie brief so uitvoerig skryf èn, op 'n paar punte na, byna al die kernpunte van die Christelike geloof en leer uiteensit? Miskien moet ons die antwoord in die volgende rigting soek: 'n Mens kan verwag dat Paulus, noudat hy meen dat sy werk in die Ooste afgehandel is, op sy afgelegde pad van evangelieverkondiging sal terugkyk. Hy stel dan ter wille van homself, ter wille van die gelowiges in Rome èn ter wille van die geslagte gelowiges wat sal kom, die hoofpunte wat uitgekristalliseer het, op skrif. Ook omdat Paulus en die gelowiges in Rome mekaar nie persoonlik ken nie, is dit te verwagte dat hy 'n taamlik uitvoerige en samehang- 
ende uiteensetting van die vernaamste punte van sy leer en prediking sal gee.

Voordat Paulus egter die gelowiges in Rome persoonlik kan ontmoet, moet hy eers die liefdegawe van die gemeentes aan die arm Christene in Jerusalem oorbring. Hy verwag daar allerlei probleme, selfs vervolging en dood ter wille van die evangelie van Jesus Christus. Daarom vra hy die gelowiges in Rome "om saam met my in die gebede vir my te stry by God".

\section{DIE SENTRALE TEMA}

Om 'n sentrale tema vir ' $n$ brief van Paulus aan te wys, hou die gevaar in dat ander belangrike temas in die brief of verwaarloos òf skeefgetrek kan word. Omdat die brief van Paulus aan die Romeine egter 'n samehangende geheel vorm en as't ware self 'n sentrale tema aanwys, kan ons dit wel in hierdie geval doen. Hierdie sentrale tema wentel om die vraag: Hoe kan die saak van die sondige mens reggemaak word met God sodat hy voor God kan staan en kan leef as 'n versoende, regverdige mens en kind wat uiteindelik die gawe van die ewige lewe sal beërwe? Negatief word gestel: Hierdie regstelling, hierdie regverdigmaking van die mens, geskied nie deur die werke wat die wet van God vereis, te doen nie. Dan sou die regverdigmaking óns verdienste wees waarop ons kan roem. Nou gebeur dit egter "sonder die werke wat die wet vra" (Rom 3 vers 28), "sonder verdienste" (Rom 3 vers 24), "aangesien uit die werke van die wet geen vlees voor Hom geregverdig sal word nie" (Rom 3 vers 20). Daarom is die roem uitgesluit (Rom 3 vers 28). Objektief is die moontlikheid van die regstelling van die sondaar se saak en posisie voor God die versoeningsdood van Jesus Christus (Rom 3 vers 25) wat "vir ons gesterf het toe ons nog sondaars was" (Rom 5 vers 8). Maar ook Jesus Christus se opstanding en opstandingslewe (bv. Rom 6 vers 4, 5 en $8-11$ ) en verder sy hemelvaart en sy regering en intrede vir ons in die hemele by die Vader (bv. Rom 8 vers 34), is objektiewe feite wat vir die regstelling van ons posisie voor God en die dankbare lewe wat daaruit volg, van groot betekenis is. Maar hoe staan die saak nou subjektief, d.w.s. hoe kry die mens van sý kant af deel aan hierdie regstelling; hoe word die mens voor God geregverdig? Die antwoord hierop is: Alleen deur die geloof in Jesus Christus! In Rom 3 lees ons die volgende in hierdie verband: Die geregtigheid van God word "die geregtigheid van die geloof in Jesus Christus" genoem en dit word (so 
sê Paulus), geopenbaar "vir almal en oor almal wat glo" (vers 21 en 22). Van God word gesê dat Hy "regverdig maak wie uit die geloof in Jesus Christus is" (vers 26). Dit staan dus vas "dat die mens geregverdig word deur die geloof, sonder die werke van die wet" (vers 28). God regverdig "die besnedenes uit die geloof en die onbesnedenes deur die geloof" (vers 30). In Romeine 4 word gestel: "Abraham het in God geglo, en dit is hom tot geregtigheid gereken" (vers 3 en ook vers 5 en 9). Die besnydenis word in Abraham se geval "'n seël van die geregtigheid van die geloof" genoem.

Besonder belangrik in hierdie verband is Rom 1 vers 16 en 17 waar Paulus sê: "Want ek skaam my nie oor die evangelie van Jesus Christus nie, want dit is krag van God tot redding vir elkeen wat glo, eerste vir die Jood en ook vir die Griek. Want die geregtigheid van God word daarin geopenbaar uit geloof tot geloof, soos geskrywe is: "Maar die regverdige sal uit die geloof lewe." Die sinsnede: "Want die geregtigheid van God word daarin geopenbaar uit geloof tot geloof", kan nog duideliker soos volg vertaal word: "Want dit word duidelik hoe God die verhouding tussen Hom en die mens weer regstel: Dit begin by die geloof en eindig met die geloof." Dan haal Paulus uit Habakuk 2 vers 4 aan en sê: "Die Skrif sê self: Dié een wie se verhouding met God reggestel is, sal deur die geloof lewe." Die bedoeling is dan dat indien iemand se verhouding met God reggestel is, indien sy saak voor God in die reine gebring is, sal so 'n iemand uit dankbaarheid sy lewe volgens die geloof uitlewe. Hoe so 'n lewe uit die geloof daar uitsien, beskrywe Paulus bv. in Rom 8 èn 12 vers 1 tot 15 vers 13 . Onder andere vind ons in Rom 14 vers 23 die baie belangrike reël vir al ons gesindhede en handelinge, naamlik: "alles wat nie uit die geloof is nie, is sonde" .... Maar' $n$ beter vertaling van hierdie aanhaling uit Habakuk in die verband waarin Paulus dit hier gebruik, is die volgende: "Dié een wie se verhouding met God deur die geloof reggestel is, sal lewe." Die bedoeling is dan die volgende: Daar is die Jode wat meen dat hulle "regverdiges uit die wet" is, dit wil sê wat meen dat hulle verhouding met God reggestel kan word wanneer hulle die voorskrifte van die wet nakom. Dit is egter nie so nie; hierdie mense sal sterwe in die sin dat hulle nie die ewige lewe sal beërwe nie. Daar is egter ook "die regverdiges uit die geloof", dit wil sê hulle wie se verhouding met God deur die geloof in Jesus Christus reggestel is. Van hulle sê Paulus: Hulle sal lewe. Dit beteken twee dinge: Hulle sal die ewige lewe beërwe èn hulle sal (soos ons vroeër aangetoon het) uit die geloof hulle aardse lewe tot eer van God inrig 
soos bv. Rom 8 èn 12 vers 1 tot 15 vers 13 dit beskrywe. Ons kan dit baie kort stel deur te sê: "Die mens wie se saak voor God deur die geloof reggestel is, sal deur en uit die geloof lewe."

\section{DIE GELOOF}

1. Die geloof in Jesus Christus is dus die wyse wat God verkies het om die mens regverdig te maak, om die mens se saak en posisie voor Hom reg te stel. Dit blyk o.a. uit die geskiedenis van Abraham wat in "God geglo het, en dit is hom tot geregtigheid" (Rom 4 vers 3). As Abraham se verhouding met God deur sy eie goeie dade ("die werke van die wet") reggestel sou gewees het, sou dit beteken het dat die mens deur sy eie verdienste voor God geregverdig word. Maar nou word die mens se saak met God reggemaak "uit die geloof, sodat dit volgens die genade kan wees" (Rom 4 vers 16). Dit is nie só dat alleen die heidene deur die geloof gered word, en die Jode deur die verdienstelike goeie werke wat hulle volgens die voorskrifte van die wet doen nie. Abraham het die belofte dat hy die vader van baie nasies sou wees, vóór sy besnydenis ontvang sodat dit duidelik kan word dat beide die besnedenes (die Jode) èn die onbesnedenes (die nieJode) nie anders as deur die geloof gered word nie (Rom 3 vers 30 èn 4 vers 10 tot 16 ).

2. Die inhoud van hierdie geloof is "die evangelie van Jesus Christus wat 'n krag van God tot redding is, vir elkeen wat glo" (Rom 1 vers 16). Hierdie evangelie van Jesus Christus sê eerstens vir ons wie Jesus Christus is en tweedens wat Hy gedoen het. Wie Jesus is, som Paulus in hierdie brief baie kort soos volg op:

(a) Jesus Christus is die ewige Seun van God, ons Heer. Dit het God "op kragtige wyse laat blyk ... deur sy opstanding uit die dode" (Rom 1 vers 4 ).

(b) "Wat sy mensheid betref, is Hy uit die geslag van Dawid gebore" (Rom 1 vers 3 ) en het $\mathrm{Hy}$ "vlees" geword, waaragtige mens net soos ons....

Soos o.a. in 1 Kor 15 vers 3 en 4 sonder Paulus uit die baie dinge wat Jesus gedoen het, twee heilsfeite uit as die kernpunte waarom alle ander draai, naamlik sy kruisdood en opstanding.

(i) Wat sy kruisdood betref, sê hy "dat Christus vir ons gesterf het toe ons nog sondaars was". Die feit dat Christus gesterf het, is 
belangrik, maar óók die feit dat Hy vir ons gesterf het, "vir ons sondes" ( 1 Kor 15 vers 3 ) is betekenisvol. Daardeur "is ons geregverdig deur sy bloed ... is ons met God versoen deur die dood van sy Seun" (Rom 5 vers 8 tot 10).

(ii) Wat Jesus Christus se opstanding betref, sê Paulus in 1 Kor 15 vers 14,17 en 32 dat as Christus nie opgestaan het nie, dan is die prediking, ons geloof en ons lewe uit die geloof tevergeefs en nutteloos, want dan is die sonde en dood nie oorwin nie en het ons geen waarborg vir ons eie opstanding en ewige lewe nie. Hier in Romeine sê Paulus dat Jesus Christus "opgewek is ter wille van ons regverdigmaking" (Rom 4 vers 25). Ons "word gered deur sy lewe noudat ons versoen is" (Rom 5 vers 10) en dit voer uiteindelik "tot die ewige lewe deur Jesus Christus, ons Here" (Rom 5 vers $21 ; 6$ vers 22 en 10 vers 9 ).

3. Die geloof in Jesus Christus het sy oorsprong in die prediking van die Woord van God deur die werking van die Heilige Gees. Helder en duidelik skryf Paulus hieroor in Rom 10 vers 13 tot 17 . In vers 13 haal hy Joël 12 vers 32 aan wat sê: "Elkeen wat die Naam van die Here aanroep, sal gered word." Om God se Naam aan te roep, beteken om op sy hulp te vertrou, tot Hom te bid, in Hom te glo en Hom te bely. Nou vra Paulus: Hoe kan mense sy Naam aanroep, as hulle nie in Hom glo nie en hoe kan hulle in Hom glo, as hulle nie sy gepredikte woord gehoor het nie? Dan sluit hy af deur te sê: "Die geloof is dus uit die gehoor, en die gehoor is deur die woord van God" (Rom 10 vers 17 ).

4. Die werking van die geloof word in hierdie brief op verskillende maniere beskrywe, maar die treffendste uiteensetting in hierdie verband kry ons in Romeine 6. Soos die doop aandui, word ons deur die geloof op ' $n$ baie innige wyse aan Jesus Christus verbind, as't ware op Hom ingeënt, soos 'n tak op 'n boom (Rom 6 vers 3 tot 5 vers 5 praat van "met Hom saamgroei"). Maar nou is Hy op wie ons deur die geloof ingeënt is, tegelyk $\mathrm{Hy}$ wat aan die kruis gesterf het èn Hy wat die dood oorwin het en lewe. Ons inenting op Hom beteken dan eerstens dat ons op Hom wat gesterwe het, ingeënt is. Die tak wat op ' $n$ boom wat gesterf het, ingeënt is, sterf saam met die boom en dieselfde gebeur met ons wanneer ons ingeënt is op Jesus Christus wat gesterf het (vgl. Rom 6 vers 3 tot 6, 8 en 11). Maar "wat" van ons het deel aan die kruisdood van Christus? Paulus sê "dat ons oue mens saam gekruisig is" en dat daardeur "die liggaam van die sonde 
vernietig is" (Rom 6 vers 6). Hierdie "oue mens" en "liggaam van die sonde" wat saam met Christus gekruisig en sodoende vernietig is, is ons "sondige natuur en lewe". So het die kruisdood van Christus die sonde vernietig. Die gevolg daarvan is dat ons daardeur vergiffenis van sondes het met die oog op die ewige lewe èn dat óns in hierdie lewe vir die sonde dood moet wees en die sónde vir ons sodat "ons nie meer die sonde sou dien nie" (Rom 6 vers 6). Maar ons inenting op Hom beteken tweedens dat ons op Hom wat die dood oorwin het en lewe, ingeënt is (Rom 6 vers $4,5,8,13$ ). Paulus verklaar hierdie verband soos volg: 'n Mens moet die wil doen van hom wat jou baas is (Rom 6 vers 16). Vroeër was die sonde ons baas en het ons hom gedien en gehoorsaam èn sy wil gedoen, naamlik die ongeregtigheid (Rom 6 vers 12, 13, 14, 16 en 17). Dit het tot die dood gevoer (Rom 6 vers 16 en 23). Deur die sonde en die dood te oorwin, het Jesus Christus ons vrygemaak van die sonde en die dood en het Hý (en God die Vader) nou ons Heer geword en ons sy diensknegte. Dit beteken dat ons nie meer die wil van die sonde moet doen en die sonde moet dien nie, maar dat ons die wil van ons ware Heer "van harte" moet doen (vers 17), die geregtigheid moet nastreef èn tot God se eer moet lewe. "Maar nou dat julle vrygemaak is van die sonde en diensbaar geword het aan God, het julle julle vrug tot heiligmaking en uiteindelik die ewige lewe" (Rom 6 vers 22). Kortom: Om in Hom die opgestane en lewende Heer deur die geloof ingeënt te wees, beteken dat ons sodoende deel aan die ewige lewe kry èn dat ons, wat hierdie lewe betref, "ook so in 'n nuwe lewe kan (èn moet) wandel" (Rom 6 vers 4).

5. Die vrugte van die geloof het alreeds telkens ter sprake gekom. Ons het alreeds gesien dat Paulus hier in Romeine 6 as vrugte die volgende noem: die ewige lewe (vers 22 en 23), gehoorsaamheid aan die geregtigheid (vers 18 en 19) en heiligmaking (vers 19 en 22). Romeine 5 noem die volgende vrugte van die geloof: vrede by God deur onse Here Jesus Christus (vers 1); hoop op die heerlikheid van God (vers 2); lydsaamheid en selfs roem in verdrukking (vers 3 ); die liefde van God wat in ons harte uitgestort word deur die Heilige Gees wat aan ons gegee is (vers 5). Die feit dat die Heilige Gees in verband met die vrugte van die geloof genoem word, is belangrik, want dit is die Heilige Gees wat deur die prediking van die woord die geloof in ons werk sodat die vrugte van die Gees (wat Galasiërs 5 vers 22 so pragtig beskryf) èn die vrugte van die geloof presies dieselfde is. Paulus 
beskryf die vrugte van die geloof as vrugte en werkinge van die Gees o.a. in Romeine 8. Hier noem Paulus dié mense wie se baas die sonde is, "vleeslik". Hulle lot is uiteindelik die ewige dood (vers 5-7). Diegene wat deur die Gees deur die geloof aan Christus as hulle opgestane en lewende Heer verbonde is, noem Paulus "geestelik". Hulle behoort aan Christus (vers 9), dien en doen nie meer die sonde nie (vers 10), sal die ewige lewe verkry (vers 11), noem God hulle Vader (vers 15 en 16) en is as kinders van God mede-erfgename van die ewige lewe en heerlikheid (vers 17). In hierdie lewe hoop en wag hulle op die heerlike eindtyd (vers 25) en weet dat vir die geroepenes alles ten goede meewerk (vers 28). Hulle "is versekerd dat geen dood of lewe, engele of owerhede, magte, teenwoordige of toekomende dinge, hoogte of diepte of enige ander skepsel ons sal kan skei van die liefde van God wat daar in Christus Jesus, ons Heer is nie" (vers 38 en 39).

\section{ISRAEL}

Gesien die sterk verband tussen Israel en die Christendom en gesien die feit dat Paulus self vroeër 'n gelowige Israeliet, was, was daar meer as genoeg aanleiding vir Paulus om oor die probleemsituasie te skryf wat rondom Israel ontstaan het met die koms van Jesus Christus en die opkoms van die Christendom.

Paulus beskryf in Rom 9 vers 4 en 5 Israel se posisie soos volg: Hulle is God se volk; Hy het hulle as sy kinders aangeneem en $\mathrm{Hy}$ het sy heerlikheid aan hulle geopenbaar; Hy het herhaaldelik sy verbond met hulle gesluit en sy Wet aan hulle gegee; by hulle het God sy tempel en diens gehad en aan hulle is die nakomelinge van die beroemde Hebreeuse voorvaders - ja, uit hulle is Christus, sover dit sy menslike afstamming betref, gebore. In Rom 3 vers 1 en 2 sê Paulus dat die voordeel van die Jood in baie opsigte groot is, veral daarin dat "die woorde van God aan hulle toevertrou is". In Rom 2 vers 17-20 stel hy verder dat die feit dat die Jood die Wet het en daaruit onderrig is, meebring dat hy die wil van God ken en kan "onderskei dié dinge waar dit op aankom".

Die probleem rondom Israel ontstaan vir Paulus basies vanweë twee redes: Die eerste is dat verreweg die meeste Jode nie Jesus Christus in die geloof as die Saligmaker aanvaar het nie, maar Hom verwerp het. Die tweede rede is dat by hulle die gedagte gelewe het 
dat die mens gered kan word deur dié werke wat die wet vra, te doen en sodoende jou eie geregtigheid op te rig (bv. Rom 10 vers 3 en 5). Hierdie gedagte staan juis lynreg teenoor die sentrale tema wat Paulus in die brief aan die Romeine uitwerk, naamlik beide Jode èn heidene "doemwaardig voor God is" (Rom 3 vers 19) en nie anders as slegs deur die geloof in Christus Jesus gered kan word nie (Rom 3 vers 21 tot 30 en 10 vers 4 en 6 tot 17). Vanuit hierdie sentrale tema moes Paulus hom dus met die probleem van Israel besig hou.

Die kernvraag in hierdie verband is: "Het God dan miskien sy volk verstoot?" (Rom 11 vers 1 ) en het "die woord van God" (Rom 9 vers 6), sy "onberoulike roeping" en "beloftes" dan verval? (Rom 11 vers 29). In die beantwoording van hierdie vraag, bring Paulus 'n hele aantal baie belangrike sake na vore:

(a) Ook in die tyd van die Ou Testament is geen Israeliet outomaties gered bloot omdat hy vleeslik 'n nakomeling van Abraham en so lid van die uitverkore volk was nie. Diegene in die uitverkore volk wat ongehoorsaam was, is deur God verwerp. As die grootste deel van Israel nou verwerp word, word hulle verwerp vanweë hulle ongeloof (Rom 11 vers 20), hulle ongehoorsaamheid (Rom 11 vers 30,31 en 32 asook Rom 10 vers 21 ) en eiegeregtigheid (Rom 10 vers 3 ). In hierdie opsig is die posisie in die $\mathrm{Ou}$ èn in die Nuwe Bedeling presies dieselfde.

(b) In die tyd van die Ou Testament het die feit dat Israel die uitverkore volk van God was, nie beteken dat die hele volk geglo het nie. Dikwels was daar maar 'n baie, baie klein "oorblyfsel" wat geglo het (Rom 9 vers 27 en 11 vers 3 tot 5). Die feit dat daar slegs 'n klein "oorblyfsel" was, het dus nie beteken dat die saak van Israel as die uitverkore volk van God ò die onberoulike roeping en beloftes van God verval het nie en dat God ontrou geword het nie. So is dit ook nou in die Nuwe Bedeling. Al glo net ' $n$ paar natuurlike nakomelinge van Abraham, dan bly die roeping, beloftes en woord van God teenoor Israel èn God se trou nog vas en seker staan.

(c) Buitendien was die uitverkore volk van God nooit die uitverkore volk, bloot omdat hulle vleeslik van Abraham, Isak en Jakob afgestam het nie. Van Abraham se afstammelinge het God Isak uitverkies en nie Ismael nie (sien bv. Gal 4 vers 22-31); van die nageslag van Isak het God Esau verwerp en Jakob (wat ook "Israel" genoem is) uitverkies (Rom 9 vers 10 tot 13). Dus nie vleeslike afstamming nie, maar goddelike uitverkiesing laat ie- 
mand tot die uitverkore volk van God behoort. As God nou ook mense uit die heidene wat vroeër nie sy volk was nie, uitverkies dan word hulle nou deel van sy uitverkore volk (Rom 9 vers 25 en 26), deel van "die Israel van God" (Gal 6 vers 16) wat "geroep is uit die Jode, maar ook uit die heidene" (Rom 9 vers 24).

(d) Rondom die vrymagtige uitverkiesing van God ontstaan daar egter die vraag: "Is daar miskien onreg by God?" (Rom 9 vers 14) wanneer $\mathrm{Hy}$ byvoorbeeld Isak en nie Ismael nie, uitverkies; ò Jakob en nie Esau nie en wanneer nou slegs 'n klein uitverkore oorblyfsel van Israel na die vlees glo? Paulus antwoord: "Nee, definitief nie!" (Rom 9 vers 14). Eerstens nie, omdat (soos ons vroeër aangetoon het) diegene wat nie glo nie, deur hulle eie skuld verlore gaan en tweedens omdat die skepsel nie teenoor die soewereine Skepperheer kan vra: "Waarom het u my nie só gemaak nie?" Want die pottebakker kan tog met sy klei maak wat Hy wil (Rom 9 vers 20 en 21). Die troos wat die vrymagtige uitverkiesing van die soewereine God bied, is dat die mens se saligheid nie rus op die wankele fondament van die mens se wil (Rom 9 vers 16) of prestasie (Rom 9 vers 11) nie, maar op die onwankelbaarheid van God se voorneme, barmhartigheid en ontferming (Rom 9 vers 11 en 16).

(e) Maar al het God die grootste gedeelte van die volk Israel na die vlees verwerp as gevolg van hulle ongeloof, ongehoorsaamheid en skuld (soos ons hierbo aangetoon het), het God in sy goedheid ook uit hierdie verskriklike gebeurtenis iets goeds laat voortkom. God het die vleeslike Israel se val gebruik sodat "deur hulle val die saligheid tot die heidene gekom het" (Rom 11 vers 11) en sodat "hulle verwerping, die versoening van die wêreld" kon wees (Rom 11 vers 15). Paulus vergelyk Israel na die vlees van die Ou Testament met 'n mak olyfboom en die heidene met wilde olyfboomtakke. Nou sê hy: God het takke van die mak olyfboom afgebreek. "Deur ongeloof is hulle afgebreek" (Rom 11 vers 20). Die Christene wat vroeër heidene was, kan nou sê: "Die takke is afgebreek, sodat ek ingeënt kon word" (Rom 11 vers 19). Die Christene uit die heidendom mag egter nie oor hierdie feit hoogmoedig wees, Israel verag en in ongeloof verval nie, want "anders sal jy ook afgekap word" (Rom 11 vers 20, 22 en 25). "Want as God die natuurlike takke nie gespaar het nie, sal Hy miskien jou ook nie spaar nie" (Rom 11 vers 21). Daar wag egter 'n heerlike toekoms op Israel na die vlees as hulle Jesus Christus 
in die geloof aanneem. As God die heidene "wat van nature wild was", "teen die natuur op die mak olyfboom ingeënt" het, "hoeveel te meer kan hulle dan wat dit van nature is, op hulle eie olyfboom ingeënt word?" (Rom 11 vers 24). Dit sal gebeur "as hulle nie in die ongeloof bly nie" (Rom 11 vers 23 ).

\section{DIE CHRISTELIKE LEWE}

1. In bostaande uiteensetting het dit telkens geblyk watter geweldige gevolge die regstelling van die mens se saak en posisie voor God deur die geloof in Jesus Christus vir die persoonlike lewe van die gelowiges het. Omdat hulle deur die geloof ingeënt is op die gekruisigde Christus, het hulle saam met Hom gesterwe. Dit beteken dat hulle die sonde afgesterf het en doof moet wees vir die roepstem en lokstem van die sonde. Omdat hulle óók op die opgestane Heer wat lewe ingeënt is deur die geloof, beteken dit dat hulle nou in 'n "nuwe lewe moet wandel". Dit beteken ook dat die sonde nie meer hulle baas is nie. Daarom moet hulle hulle nie meer deur die sonde laat rondorder om die sonde se wil te doen nie, maar moet hulle hulle Heer dien wat hulle vrygemaak het van die slawerny van die sonde. Hoe die persoonlike lewe van 'n gelowige behoort te wees, kan ons in Romeine 8, 12 en 15 lees.

2. Maar die regstelling van die mens se saak en posisie voor God deur die geloof in Jesus Christus het nie net vir die persoonlike lewe gevolge nie, maar ook -

(a) vir die samelewing van mense in die kerk èn;

(b) vir die samelewing van mense in die "staat".

(i) Wat die saamleef van mense in die gemeenskap van die kerk betref, raak Paulus twee baie belangrike sake aan: Eerstens praat hy oor die saak van genadegawes en tweedens oor die houding van die gelowiges teenoor hulle wat "swak is in die geloof" (Rom 14 vers 1) .... Wat die genadegawes betref, praat hy in Rom 12 vers 3-8 daaroor. Daar sê hy dat daar 'n verskeidenheid van genadegawes is en tog ' $n$ eenheid soos die één liggaam baie lede het (vers 4). Die doel waarom God 'n genadegawe aan ons gee, is nie om daarmee te spog en onsself te verhef nie (vers 3), maar om "na die maat van geloof wat God aan ons toebedeel het", Christus te dien èn die lede van die gemeente afsonderlik (vers 3 en 5 ). 
In sy ryke genade skenk God 'n verskeidenheid gawes sodat in die veelheid van behoeftes van sy gemeente voorsien kan word. As Hy net één soort genadegawe sou skenk, sou die ander fasette van sy werk skade ly. Die eenheid van die baie gawes lê eerstens daarin dat almal van die één God kom en tweedens daarin dat hulle nie tot jaloerse naywer en skeuring moet lei nie, maar God se een kerk moet dien ... Die saak van hulle wat "swak is in die geloof" behandel Paulus in Rom 14 vers $1-23$. Die saak was naamlik só, dat hulle wat nou Christene is, uit godsdienste (soos die Joodse geloof) gekom het waar één van die belangrike dinge was, die seremoniële onderskeiding tussen rein en onrein, heilig en onheilig. In daardie godsdienste was dit sonde om iets onreins te eet (vers 2 en 15) of om iets op 'n heilige dag te doen (vers 5 en 6). In die Christendom staan sake egter anders: Christus het ons vrygemaak van die seremoniële wet en alles kom aan op die innerlike gesindheid en geloof in Christus. "Niks is op sigself onrein nie" (vers 14), d.w.s. in godsdienstig-seremoniële sin nie. Nou het dit gebeur dat sommige wat vanuit die Joodse geloof tot die Christelike geloof oorgekom het wel met hulle verstand geweet het dat in Christus die onderskeiding rein-en-onrein verval het, maar diep in hulle hart het hulle tog gegril en dit as sonde beskou as iemand iets onreins eet of op die Joodse Sabbat sou werk. Hierdie mense noem Paulus "hulle wat swak is in die geloof". Maar daar was ook diegene wat die vrymaking vanuit die seremoniële wet deur Christus ten volle aanvaar het en geen beswaar gehad het om iets onreins te eet of om nie op die Joodse Sabbat te rus nie. Die gevaar was dat deur hierdie twee houdings van twee groepe mense, daar tweespalt en skeuring in die kerk kon kom. Die "swakkes" het die "sterkes" veroordeel en gedink so 'n losbol kan g'n ware Christen wees nie (bv. vers 3), terwyl die "sterkes" weer die "swakkes" verag het as bekrompe mensies (ook vers 3). Nou sê Paulus dat albei, die "swakkes" èn die "sterkes" in die strik van werkheiligheid en eiegeregtigheid kan val deur te dink: "Ek is die regte soort Christen, omdat $e k$ só en só doen of nie doen nie! Die konserwatisme van die "swakkes" kan tot wettiese, selfvoldane, eiegeregtige, skynheilige bekrompenheid voer, terwyl die vryheid van die "sterkes" kan lei tot eiegeregtige, kritiese hoogmoed en selfverheffing. Skeuring kan alleen vermy word wanneer elke groep besef: In die kerk gaan dit nie oor die reg van my standpunt nie, maar om die eer van God 
(vers 6 en 8). Die gemeente moet besef: "Niemand van ons leef vir homself nie en niemand sterf vir homself nie", maar "as ons leef, leef ons tot eer van die Here en as ons sterwe, sterf ons tot eer van die Here" (vers 7 en 8 ).

Paulus laat deurskemer dat "die sterkes" in werklikheid 'n beter besef het van die werklike vrymakende, verlossende krag van die geloof in Jesus Christus (vers 14 en 16 tot 20). Maar nou is daar 'n gevaar wat nie soseer die "sterkes" raak nie, maar die "swakkes". 'n Te ooglopende uitlewing van die "sterkes" se vryheid in Christus, veral wanneer "swakkes" toekyk, kan nie net die swakke grief en aanstoot aan hom gee nie, maar "hom te gronde rig vir wie Christus gesterf het" (vers 15) en so kon "ter wille van voedsel die werk van God afgebreek word" (vers 20).

Daarom beveel Paulus by die "sterkes" die volgende gedragspatroon aan. "Op ons wat sterk is, rus die verpligting om die swakhede te dra van die wat nie sterk is nie, en nie onsself te behaag nie" (Rom 15 vers 1). Die "sterkes" moet hulle vryheid deur die liefde laat begrens (Rom 4 vers 15), want liefde beteken o.a. om eie reg en aansprake ter wille van ' $n$ ander prys te gee. Ons moet "mekaar aanneem soos Christus ons ook aangeneem het" (Rom 15 vers 7), want sý liefde het onder andere beteken dat Hy alles opgeoffer het ter wille van ons wat swak is.

(ii) Ons regverdigmaking deur die geloof het egter óók gevolge vir die manier waarop ons in staatkundige verband met mekaar saamleef en veral vir ons siening en waardering van die burgerlike owerheid. Paulus behandel dié aangeleentheid in Rom 13 vers $1-7$. Die volgende baie belangrike perspektiewe word hier deur Paulus na vore gebring:

- Die burgerlike owerheid is ' $n$ instelling van God (vers 1 en 2).

- Die burgerlike owerheid is deur God met mag beklee, selfs die mag om dood te maak, sodat hy sy taak kan uitvoer (vers 1, 3 en 4).

- Die doel van die burgerlike owerheid is dat "hy ' $n$ dienaar van God, jou ten goede" om hulle wat goed doen te prys en hulle wat kwaad doen te straf (vers 3 en 4).

- Die plig van die onderdane teenoor die burgerlike owerheid, is die volgende: Eerstens moet hulle die finansiële middele (soos tol en belasting) aan die owerheid gee sodat hy sy taak kan verrig (vers 6 en 7). Tweedens moet hulle die owerheid 
vrees en eer (vers 7). Derdens moet hulle die burgerlike owerheid gehoorsaam en hulle aan hom onderwerp. Dit moet hulle doen, want as hulle dit nie doen nie, sal die owerheid hulle straf met dié mag wat God aan hom gegee het (vers 5). Maar hulle moet dit veral doen "ter wille van hulle gewete" (vers 5), dit wil sê: hulle moet die owerheid gehoorsaam omdat God dit beveel en ons God se bevel nie mag weerstaan nie (vers 2).

En nou moet ons onthou dat dié owerheid waarvan Paulus hier praat, nie eens 'n Christelike owerheid was nie. Dit was dieselfde Romeinse owerheid wat op onwettige wyse Jesus Christus ter dood veroordeel het en Paulus dikwels op onwettige wyse gestraf het. En tog stel Paulus dat die gelowiges hierdie owerheid positief moet waardeer as gawe van God ons ten goede. God se woord is beslis anti-revolusionêr.

\section{DIE LOFPRYSING}

Hierbo het dit geblyk dat die regstelling van ons saak en posisie voor God gevolge het vir die ewige lewe, vir die persoonlike lewe, vir die lewe in die kerkverband èn in die staatsverband. Maar dit het veral gevolge vir ons verhouding teenoor God. Aan Hóm moet die lof en dank gebring word. Miskien is een van die mooiste lofprysings in die Bybel juis dié een wat in Romeine 11 vers 33-37 staan: "O, diepte van die rykdom en wysheid en kennis van God! Hoe ondeurgrondelik is sy oordele en onnaspeurlik sy weë! Want wie het die gedagte van die Here geken, of wie was sy raadsman gewees? Of wie het eers iets aan Hom gegee, dat dit hom vergeld moet word? Want uit Hom en deur Hom en tot Hom is alle dinge. Syne is die heerlikheid tot in ewigheid. Amen." 